\title{
Refleksje nad historią nauki na marginesie książki Stefana Zameckiego Życie wśród innych, Warszawa 2019
}

\section{Reflections on the history of science on the margins of Stefan Zamecki's Życie wśród innych [Life among Others], Warsaw 2019}

The author, inspired by Stefan Zamecki's autobiography: Życie wśród innych [Life among Others] and the life-path of this scholar, reflects on Polish historiography of science. These deliberations are not free from personal notes and associations referring to the figures of Polish historiography of science and the hero of the analysed book. Jaromir Jeszke uses here a flexible formula of Reflections on the margins of... From the theoretical perspective of the history of science, the author finds the following fields of Stefan Zamecki's activity particularly inspiring: 1) his attempts to introduce - and consistently use in his works - the concept of 'science' and its subdisciplines, e.g. 'chemistry'; 2) organising and conducting (together with Prof. Alina Motycka, philosopher from the Institute of Philosophy and Sociology of the Polish Academy of Sciences) a nationwide seminar: 'Context of discovery in the history of the field of science', which was held from the mid-1990s to 2002; 3) his scientific vision of the history of science together with its organizational location among sciences on science; 4) his analytical studies on a scientific journal with a century-old tradition: Nauka Polska. Jej Potrzeby, Organizacja i Rozwój [Polish Science. Needs, Organization and Development]. Stefan Zamecki appears to the author as a critical, skeptical and aloof scholar who walked into the history of science through studies on chemistry and philosophy. This experience has shaped his theoretical, 'boundary', not always accepted, but inspirational attitudes.

Keywords: Stefan Zamecki, biography, history of science, science studies Słowa kluczowe: Stefan Zamecki, biografia, historia nauki, naukoznawstwo 
Trudno jest pisać recenzję książki tak osobistej, jak Życie wśród innych profesora Stefana Zameckiego. Niniejszy tekst nie może więc mieć takiego charakteru. Jednakże osoby znające naukową aktywność Profesora, a do takich mam zaszczyt, jak sądzę, się zaliczać, zauważą z pewnością... to, czego w książce zabrakło lub zostało zaledwie zasygnalizowane. Niektóre z obszarów działalności, nie tylko naukowej, prof. Zameckiego, a także kontakty osobiste, kształtowały moją postawę badawczą, niekiedy wspierając projekty czy ambicje, otwierając nowe możliwości. Zawsze jednak wzbudzając refleksje. I z tej perspektywy, choć nie będzie ona wolna od akcentów osobistych, chciałbym spojrzeć na postać Profesora i jego wkład w kształtowanie się polskiej historiografii nauki i środowiska polskich historyków nauki.

Niezorientowany czytelnik, czerpiący wiedzę o autorze Życia wśród innych wyłącznie z jej kart, mógłby odnieść wrażenie, że ma do czynienia przede wszystkim z historykiem chemii. Wszak prof. Zamecki jest chemikiem z pierwszego wykształcenia, które następnie uzupełnił o studia filozoficzne, w swoich pracach podejmował tę problematykę, upominał się o godny status tej specjalizacji (historii dziedziny nauka, historii subdziedziny chemia, jak by z pewnością powiedział). I, być może, w pierwszym rzędzie za historyka chemii się uważa. Oba te kierunki studiów niewątpliwie ukształtowały jego osobowość badawczą historyka nauki decydując o obszarach zainteresowań. Jednak owo wrażenie zdaje się mylne.

Czytelnik nie może bowiem dokonać jego weryfikacji tylko na podstawie lektury książki, choć ta zawiera pełny wykaz publikacji uczonego. Przyjęta tu formuła „refleksji na marginesie..." pozwala natomiast na nieco swobodniejsze skojarzenia. U osób znających nie tylko publikacje Profesora, lecz także jego działalność organizacyjną i seminaryjną jawić się może przede wszystkim jako historyk nauki (Profesor Zamecki zapytałby w tym miejscu, co to znaczy historia nauki) o naukoznawczych zainteresowaniach. Można wśród nich wyróżnić:

1. próby wprowadzenia i konsekwentne stosowanie w swoich narracjach pojęcia „dziedzina nauka” i subdziedzin np. „chemia”; tytuł jednej z jego książek z 1988 r. wszak brzmiał Pojęcie odkrycia naukowego a historia dziedziny nauki;

2. organizację i prowadzenie wraz z filozofką prof. Aliną Motycką z Instytutu Filozofii i Socjologii PAN ogólnopolskiego seminarium „Kontekst odkrycia w dziejach dziedziny nauki", funkcjonującego od połowy lat dziewięćdziesiątych ubiegłego stulecia do 2002 r.;

3. naukoznawczą wizję historii nauki wraz z jej organizacyjnym usytuowaniem wśród nauk o nauce;

4. studia analityczne nad czasopismem naukoznawczym ze stuletnią już tradycją „Nauka Polska. Jej Potrzeby, Organizacja i Rozwój".

O ile prace z zakresu historii „subdziedziny chemia” trafiały raczej do bardzo wąskiego kręgu profesjonalnie przygotowanych odbiorców, o tyle przywołane wyżej inicjatywy prof. Zameckiego miały szansę inspirować większe grono badaczy. Spośród czterech tu wymienionych, w moim odczuciu najciekawszych z punktu widzenia teoretycznej historii nauki, obszarów aktywności prof. Zameckiego w dwóch miałem okazję bezpośrednio uczestniczyć: w prowadzonym przez niego wraz z prof. Aliną Motycką seminarium, a także gdy nieoczekiwanie dla mnie, z woli władz Kasy im. Józefa Mianowskiego, zostałem w 2015 r. redaktorem naczelnym Nauki Polskiej, podczas gdy autor Życia wśród innych od wielu już lat zasiadał $w$ gronie redakcji i poddawał krytycznej analizie funkcjonowanie 
periodyku, ostatecznie publikując trzy poświęcone mu książki i obszerny artykuł w tomie jubileuszowym „Nauki Polskiej”, wydanym z okazji stulecia pisma.

Każde z czterech wymienionych pól aktywności Stefana Zameckiego należy poddać odrębnej analizie, dając pod rozwagę czytelnika ich rolę inspiracyjną oraz zakres recepcji w środowisku polskich historyków nauki, zauważając wszakże, że niektóre ze swoich propozycji, szczególnie te dotyczące problemów nomenklaturowych, prof. Zamecki wykorzystywał w publikacjach z zakresu historii chemii. Nie można zatem przeprowadzić twardego podziału pomiędzy jego wcieleniem historyka „subdziedziny chemia” a naukoznawcą z historyczną perspektywą interpretacyjną. Jedną jeszcze uwagę warto tu poczynić. Stefan Zamecki, być może w wyniku swoich studiów filozoficznych, należał do nielicznych w Polsce historyków nauki, preferujących, by użyć metafory Jerzego Kmity, „teoretyczną historię nauki". Choć użyta przez poznańskiego uczonego w innym kontekście, dobrze określa wymienione pola aktywności Profesora.

Podjął on próbę uporządkowania pewnego chaosu terminologicznego związanego z „uprawianiem historii nauki (ściślej: dziedziny nauki)”. „Celem rozważań - jak przekonywał - [...] jest uświadomienie sobie i odbiorcom pewnych trudności i możliwości związanych z uprawianiem przez historyków nauki ich profesji"1. Uważał, że to, co bada historyk nauki, stanowi pewną dziedzinę. „Dziedzinę nauki” wyznaczają zaś instytucje, ludzie, cele, czynności, metody, wytwory. Wprowadzenie parametru czasu pozwala jego zdaniem na uzyskanie ciągu genetycznego dziedzin nauki². Pisał jednak w 1988 r.:

Termin „historia dziedziny nauki” może być rozumiany co najmniej dwojako, a to ze względu na znaną dwuznaczność terminu „historia”. W języku polskim utarł się bowiem niewygodny zwyczaj używania tego terminu bądź jako nazwy dyscypliny badającej dzieje, bądź jako nazwy samych dziejów³.

Zamecki, odwołując się do potocznej praktyki językowej, zdawał się nie zauważać, że zawodowi historycy od wielu już lat odróżniają dzieje rozumiane jako zbiór wszystkich zdarzeń będących przedmiotem badań historycznych (łac. res gestae) od historii pojmowanej jako dyscyplina badająca owe dzieje, zawierająca w sobie także relacje o przeszłości (łac. rerum gestarum), a sama problematyka obrosła sporą już literaturą przedmiotu. Na gruncie historii nauki proponuje on jednak własną terminologię. Deklaruje, że będzie używał

terminu „historia” zawsze z dopełnieniem „dziedziny nauki” jako nazwy dyscypliny badającej dzieje dziedziny nauki, terminu zaś „dzieje” zawsze z dopełnieniem „dziedziny nauki” jako nazwy przedmiotu badania tej pierwszej. [...] Termin „historia dziedziny nauki" jest przeto nazwą metanauki badającej dzieje dziedziny nauki, czyli po prostu badającej ciąg genetyczny dziedzin nauki. Termin „dzieje dziedziny nauki” można by zastąpić terminem „ciąg genetyczny dziedzin nauki”. Termin „historiografia dziedziny nauki" rezerwuję dla rozważań, które jako swój przedmiot

1 S. Zamecki, Pojęcie odkrycia naukowego a historia dziedziny nauki, Wrocław. Warszawa, Kraków, Gdańsk, Łódź 1988 , s. 179.

2 Ibid., s. 128

3 lbid. 
mają historię dziedziny nauki w podanym powyżej rozumieniu. Tak więc historiografia dziedziny nauki zajmuje wobec historii dziedziny nauki metastanowisko, czyli metametastanowisko wobec dziejów dziedziny nauki .

Wychodząc od dywagacji terminologicznych, Stefan Zamecki przedstawił własną wizję uprawiania historii nauki, w tym jej celów, jako główny postrzegając badanie dziejów stawiania i rozwiązywania problemów5 ${ }^{5}$ Koncepcję swoją przedstawił jako część książki Pojęcie odkrycia naukowego a historia dziedziny nauki (Wrocław, Warszawa, Kraków, Gdańsk, Łódź 1988), znaczenia której w swojej biografii zdaje się nie doceniać. Stanowiła ona dla niektórych historyków nauki mojej generacji, rozpoczynających swoje penetracje badawcze w latach osiemdziesiątych ubiegłego stulecia rodzaj drogowskazu, porządkującego pojęcia (nauka, kontekst odkrycia/kontekst uzasadnienia, odkrycie naukowe itp.), dającego też przegląd dwudziestowiecznej filozofii i historiografii nauki.

Fragment książki zawierający własne stanowisko Zameckiego nie jest w niej eksponowany i nie spotkał się z szerszą recepcją. Dla zawodowych historyków spory terminologiczne zostały dawno rozstrzygnięte, nie towarzyszyło im natomiast głębsze zainteresowanie teoretycznymi aspektami historii nauki. Podobne stanowisko zajęła część polskiego środowiska historyków nauk szczegółowych, znających tylko podstawy warsztatu historycznego, uzyskane najczęściej poza regularnym studium. Ta ateoretyczność postaw wielu badaczy, aktualna także i dziś, nie tworzyła sprzyjającej atmosfery dla recepcji skrótowo przywołanych idei. Dodać tu można, że zarysowany mechanizm nie sprzyjał także innym próbom implantacji elementów teoretycznej historii nauki w środowiskach polskich historyków nauki. Losy tej podjętej przez Stefana Zameckiego nie stanowią zatem wyjątku. Niemniej dla historyka nauki niezainteresowanego historią chemii, lecz mechanizmami rządzącymi nauką, we wszelkich znaczeniach tego słowa, i krążeniem idei naukowych właśnie książka z 1988 r. może jawić się jako jedna najważniejszych w dorobku Stefana Zameckiego, choć on sam zdaje się nie przywiązywać do niej aż takiej wagi. Na jej łamach wielokrotnie przejawia się sceptycyzm wobec możliwości porozumienia się pomiędzy historykami nauki i filozofami tejże. Autor zdaje sobie sprawę z odmienności warsztatów, sposobów myślenia, przywiązania do konkretów, wydarzeń u pierwszych i myślenia abstrakcyjnego u drugich, rozbieżności pomiędzy akceptacją kulturowych uwarunkowań standardów racjonalności naukowej a ich ponadczasowością i uniwersalnością itp. A musiał przecież jako filozof znać słynne powiedzenie Imre Lakatosa, głoszące że „filozofia nauki bez historii nauki jest pusta, historia nauki bez filozofii nauki jest ślepa".

Pomimo dystansu, jaki zachowywał wobec możliwości porozumienia się wymienionych dyscyplin, w 1995 r. zainicjował jako moderator wraz z prof. Aliną Motycką ogólnopolskie, interdyscyplinarne seminarium „Kontekst odkrycia w dziejach dziedziny nauki”, organizowane wspólnie przez Instytut Historii Nauki PAN oraz Instytut Filozofii i Socjologii PAN. Nie potrafię rozstrzygnąć, czy ta swoista niekonsekwencja uczonego wynikała z głęboko zakorzenionego w świadomości filozofa nauki aforyzmu Lakatosa, wspólnej przecież dla obojga moderatorów, czy zadecydowały inne względy. W Życiu wśród innych Stefan Zamecki podkreśla inicjatywę Aliny Motyckiej, potrafiącej najwidoczniej przełamać jego 
sceptycyzm. Tytułowa metafora, określająca charakter seminarium także zapewne pochodzi od autora Życia... Uczestnicząc regularnie w seminarium przez cały okres jego trwania, bardzo wysoko oceniam tę inicjatywę. Reprezentujący historię i filozofię nauki moderatorzy zapraszali nie tylko wybranych referentów, niekoniecznie tylko z dwóch wymienionych dyscyplin, lecz również decydowali o doborze uczestników. Grono to nie było więc przypadkowe, a zaproszenia doń były w zainteresowanych środowiskach niezwykle cenione. Ważną cechą tych spotkań był ich regularny, comiesięczny charakter. Fakt ten mówi sam za siebie. Dla różnych krajowych środowisk historyków i filozofów nauki, pracujących na co dzień według różnych tradycji i szkół naukowych seminarium stało się ważną platformą wymiany poglądów, integracji, inspiracji, niekiedy także sporów.

Sceptycyzm Stefana Zameckiego okazał się jednak w wysokim stopniu uzasadniony. Narracje historyków i filozofów, praktyków i teoretyków w badaniach historycznych nie zawsze znajdowały wspólny mianownik. W ostatnich latach funkcjonowania seminarium zdawał się dominować nurt filozoficzny. W 2002 r. zostało ono rozwiązane ze względu, jak pisze w Życiu... Stefan Zamecki, „zbyt silnej na nim dominacji profesjonalnych filozofów, a coraz słabiej zaznaczającej się działalności profesjonalnych historyków dziedziny nauka"6.

Stałem wówczas na stanowisku, że decyzja ta była błędem, i zdania tego nie zmieniłem. Przywołany wyżej powód stanowiłby w mojej opinii raczej uzasadnienie kontynuacji seminarium „Kontekst odkrycia w dziejach dziedziny nauki”, choć przyjmuję za możliwe po prostu wypalenie się pary moderatorów. Organizacja 63 regularnie odbywających się spotkań podejmujących ważką problematykę była wszakże nie lada osiągnięciem, okupionym dużym wysiłkiem. Za jego kontynuacją przemawiało jednak, paradoksalnie, właśnie małe zainteresowanie historyków nauki ujęciami teoretycznymi. Było to bowiem wówczas jedyne poważne ogólnopolskie forum, na którym można było popularyzować „teoretyczną historię nauki" w środowisku preferującym raczej zdarzeniową, klasyczną wizję studiów historyczno-naukowych, uprawianych niekiedy w nieco archaicznej formie. Stanowiło szansę na modernizację polskiej historiografii nauki. Choć przedwcześnie rozwiązane, seminarium Aliny Motyckiej i Stefana Zameckiego zakreśliło jednak możliwe pola krążenia idei pomiędzy filozofami i historykami nauki. Przy czym należy podkreślić, że choć tytułowa metafora seminarium niewątpliwie pochodziła od Stefana Zameckiego i w jego języku określała zakres uprawianego tam dyskursu, to jednak nie miał on w zwyczaju preferowania swojej koncepcji uprawiania historii nauki i stosowanej tam nomenklatury, choć sam w swoich pracach był tu bardzo konsekwentny. Seminarium w ciągu siedmiu lat swojej działalności wypracowało sobie markę i pewien prestiż, ale ten potencjał został niestety zmarnowany. Wraz z jego zamknięciem teoretyczne rozważania nad studiami nad historią nauki czy też nauk szczegółowych uległy rozproszeniu, a impuls dla teoretycznej modernizacji polskiej historiografii nauki stał się przez to słabszy.

Ta ostatnia z trudem asymiluje światowe tendencje o charakterze syntetyzującym, "granicznym”, stawiającym współczesnej nauce ważkie pytania teoretyczne, antropologizującym, badającym z perspektywy historycznej relacje między nauką a wiedzą potoczną, geografię nauki wraz z jej centrami i peryferiami itp. Bardzo to odległe od klasycznej, 
wydarzeniowej wizji historiografii nauki, dominującej w Polsce. Jej aktualną kondycję oddaje X tom Historii Nauki Polskiej, wydany w 2015 r. przez Instytut Historii Nauki PAN pod redakcją Leszka Zasztowta i Joanny Schiller-Walickiej po kilkuletnich staraniach.

Nie jest to oczywiście bezpośrednią konsekwencją likwidacji seminarium. Można sobie jednak wyobrazić, że jego trwanie mogłoby stanowić swego rodzaju centralny kanał transmisyjny pomiędzy środowiskami polskich historyków nauki a teoretycznie zorientowanymi historykami na świecie. Natura nie znosi próżni, wyrosła więc w międzyczasie nowa generacja badaczy, a wątki tego typu zostały podjęte w kilku środowiskach (Toruń, Wrocław, Poznań) przez zainteresowanych przeszłością socjologów, filozofów czy antropologów nauki, niekiedy także pojedynczych historyków. Są to jednak inicjatywy rozproszone, a interesujące i inspirujące wątki badawcze są podejmowane coraz częściej poza środowiskiem profesjonalnych historyków nauki. Także publikowanie wyników takich studiów nie odbywa się na łamach specjalistycznych czasopism z obszaru historii nauki.

W pewnym stopniu jednoosobowo funkcję takiego kanału komunikacyjnego pełni Jan Surman, wiedeńczyk polskiego pochodzenia, dobrze znający światowe trendy historii nauki. Jego seminarium z 2017 r. w Instytucie Historii Nauki PAN poświęcone „umiejscowienia lokalnych wiedz i nauk" spotkało się jednak z umiarkowanym zainteresowaniem. Swoje teksty, wywiady z wybitnymi historykami nauki (m.in. H.-J. Rheinberger, M.G. Ash, K. Raj) i recenzje Surman publikuje jednak na łamach krakowskiej „Historyki”. Jest także tłumaczem znanych wśród europejskich historyków publikacji na język polski m.in. książki Hansa-Jörga Rheinbergera Epistemologia historyczna. Nie zmienia to faktu, że istotne teoretycznie dyskusje nad dziejami nauki toczą się dziś poza środowiskiem zawodowych historyków nauki.

Paradoksalnie stałem się do pewnego stopnia beneficjantem zaistniałej w 2002 r. sytuacji, choć ani o jotę nie zmieniłem swojego zarysowanego wyżej stanowiska. Profesor Zamecki zasugerował bowiem, abym w jakimś stopniu podjął się kontynuacji jego seminarium, a ówczesne władze IHN PAN nie zgłosiły wobec tej inicjatywy swojego sprzeciwu. Od tego czasu prowadzę pod auspicjami Instytutu i UAM, mojej macierzystej uczelni, nieregularnie interdyscyplinarne seminarium „Międzykulturowy wymiar komunikacji idei w dziejach nauki", odbywające się najczęściej w Domu Pracy Twórczej UAM w Ciążeniu nad Wartą. Ma ono jednak inny charakter i nie może spełniać roli swojego poprzednika. W ostatnich latach, pragnąc wykorzystać kompetencje, możliwości i kontakty dr. Surmana zaprosiłem go do grona redakcji „Nauki Polskiej” oraz kierowanego przeze mnie Zespołu ds. Historycznych i Społecznych Problemów Nauki, tzw. Pracowni Pytań Granicznych UAM, organizującego od dwóch lat regularnie raz w semestrze seminarium „Teoretyczna historia nauki".

Pograniczny, interdyscyplinarny charakter historii nauki od wielu lat generuje pytanie o jego dyscyplinarny status oraz organizacyjne ulokowanie. Problem nie ma wyłącznie polskiego charakteru i formy instytucjonalne przyporządkowania bywały obszarem wielu dyskusji, które nie przyniosły rozstrzygającego charakteru. Niekiedy preferowano związki z w filozofią nauki czy z historią. Zdarzały się struktury instytucjonalne o ograniczonym, tymczasowym charakterze, zanikające wraz z zakończeniem projektu badawczego lub po prostu mody ma pewien typ studiów. Stosunkowo najstabilniejsze w europejskich warunkach były i są jednostki badawczo-dydaktyczne ulokowane na uczelniach medycznych, re- 
agujące z historycznej perspektywy na ich potrzeby dydaktyczne, kulturowe i teoretyczne. Być może wynika to z głęboko zakorzenionej, ponaddwustuletniej już tradycji.

Natomiast już tylko polską specyfiką jest konsekwentne nieuznawanie historii nauki jak odrębnej dyscypliny, która to kwestia na świecie od dekad jest poza wszelką dyskusją. Kilkakrotne próby zmiany tego stanu rzeczy przez Komitet Historii Nauki i Techniki PAN oraz Instytut Historii Nauki PAN nie przyniosły efektu, a właściwe do rozpatrywania tych wniosków władze nieodmiennie je odrzucały, niekiedy z kuriozalną argumentacją, świadczącą o niezrozumieniu przedkładanych dezyderatów ${ }^{7}$.

W tym kontekście należy rozpatrywać propozycję Stefana Zameckiego organizacyjnego usytuowania historii nauki wśród nauk o nauce. Zwracał on uwagę, że

szczególne miejsce w ramach naukoznawstwa czy też nauki o nauce zajmuje „historia nauki" zajmująca się dziejami nauki (ściślej: dziejami poszczególnych nauk). Gdy jest wystarczająco upowszechniana, to przenika pozostałe metanauki. Podobnie można powiedzieć o pozostałych meta naukach, na przykład o „filozofii nauki", która coraz bardziej wkracza do zakresu historii nauki. [...] Jednak jest osobliwe, że historia nauki, a ściślej mówiąc historia poszczególnych nauk znalazła w Polsce instytucjonalne wsparcie w postaci powstania ostatecznie Instytutu Historii Nauki im. L. i A. Birkenmajerów w Warszawie, natomiast nie znalazła, mimo podejmowanych prób, takiego wyraźnego instytucjonalnego wsparcia rodzina pozostałych metanauk nazywanych zbiorczo czy to "naukoznawstwem”, czy to „nauką o nauce”. Skoro jednak powstała instytucja na poziomie historii nauki, to można mieć nadzieję, że spełnią się nadzieje tych, aby na przynajmniej jednym z polskich uniwersytetów powstał Wydział Naukoznawstwa obejmujący wszelkie istniejące dotychczas metanauki. Można byłoby go nazwać imieniem osoby, która tak dużo uczyniła dla naukoznawstwa w Polsce, a mianowicie imieniem Stanisława Michalskiego ${ }^{8}$.

Właśnie na tych pograniczach postrzega siebie Stefan Zamecki pisząc w Życiu wśród innych o swych pracach naukowych, iż „dotyczą one problematyki naukoznawczej w moim rozumieniu, a mianowicie obejmującej następujące metanauki: filozofię nauki, socjologię nauki, psychologię nauki, historię nauki, ekonomię nauki etc, a więc dyscypliny, które czynią naukę przedmiotem swych rozważań"9.

Niezależnie od oceny realnych możliwości realizacji przywołanego wyżej postulatu należy głos prof. Zameckiego uznać za istotny w tej dyskusji. Historia nauki, trans- $\mathrm{i}$ interdyscyplinarna co do swojej istoty, z niejakim trudem daje się włączyć do instytucji naukowych o jednoznacznie paradygmatycznym charakterze, niezależnie od ich dyscyplinarnej specjalizacji. I z tego powodu z reguły nie pasuje do realizowanych tam projektów badawczych, pozostając poza ich spójnym teoretycznie charakterem. Powyższa uwaga nie dotyczy wyłącznie historii nauki, lecz wszystkich grup badaczy organizujących studia,

7 J. Jeszke, Wokół statusu historii nauki w Polsce jako dyscypliny naukowej, „Nauka Polska. Jej Potrzeby, Organizacja i Rozwój" t. 25 (50), 2016, s. 65-84.

8 S. Zamecki, Problematyka naukoznawcza na łamach periodyku "Nauka Polska Jej Potrzeby, Organizacja i Rozwój". Studium Historyczno-metodologiczne, lata 1918-1947, Warszawa 2016, s. 524.

9 Idem, Życie wśród innych, s. 37. 
szczególnie o transdyscyplinarnym charakterze, przypisane do jednolitych paradygmatycznie wydziałów czy instytutów.

Otóż propozycja Stefana Zameckiego do pewnego stopnia łagodzi opisane zagrożenia, lokując historię nauki wśród subdyscyplin penetrujących wspólnie wybrany obszar badawczy - naukę. Losy seminarium „Kontekst odkrycia w dziejach dziedziny nauki” dobitnie wskazały na trudności w budowaniu wspólnych założeń badawczych pomiędzy filozofami i historykami nauki. Można domniemywać, że nie mniejsze wystąpiłyby w relacjach historii nauki z innymi dyscyplinami naukoznawczymi. Multidyscyplinarne, wspólne penetrowanie pola badawczego stwarza jednak szansę na przynajmniej tymczasowe projekty o interdyscyplinarnym charakterze, jeżeli nie między wszystkimi, to przynajmniej niektórymi subdyscyplinami badającymi fenomen nauki. Dobrym przykładem mogą tu być dzieje etnomedycyny, studiującej z różnych perspektyw społeczne zachowania wobec zdrowia i choroby. Można zatem sądzić, że organizacyjne, instytucjonalne powiązanie subdyscyplin o „naukoznawczym” charakterze ułatwiłoby zarysowane wyżej procesy, nie przesądzając wszakże o powstaniu jednolitego, interdyscyplinarnego pola badawczego.

Naukoznawcze zainteresowania Stefana Zameckiego znalazły odbicie w jego studiach nad ujęciami tej problematyki na łamach periodyku „Nauka Polska. Jej Potrzeby, Organizacja i Rozwój", wydawanego przez Kasę im. Józefa Mianowskiego od 1918 r. z przerwą na okres PRL-u. W Życiu wśród innych ten wątek zainteresowań autora został bynajmniej nie symbolicznie zaznaczony. Oznaczało to możliwość analizy początków i kształtowania się naukoznawstwa na polskim gruncie w dobie międzywojnia i refleksji nad nauką po 1992 r. w odmiennych już warunkach funkcjonowania pisma. Począwszy od 2016 r. uczony opublikował trzy książki i jeden obszerny artykuł poświęcone temu zagadnieniu. Czas wydania tych publikacji, będących z pewnością wynikiem wcześniejszych zainteresowań Stefana Zameckiego, zbiegł się z objęciem przeze mnie funkcji redaktora naczelnego „Nauki Polskiej”, jego teksty stały się zatem dla mnie źródłem refleksji nad historią pisma i polityką redakcyjną, szczególnie że odnosił się także do działań redakcji, za które byłem już odpowiedzialny.

Analizując w pierwszej z tego cyklu książek (Problematyka naukoznawcza na łamach periodyku „Nauka Polska Jej Potrzeby, Organizacja i Rozwój”. Studium Historyczno-metodologiczne, lata 1918-1947, Warszawa 2016) dorobek pionierów polskiego naukoznawstwa: Floriana Znanieckiego, Marii i Stanisława Ossowskich i Tadeusza Kotarbińskiego, autor zwrócił uwagę na potencjał studiów pierwszego z nich w zakresie historii nauki. Choć więc Znaniecki w swoim studium sporo miejsca poświęcił historii wiedzy, to zgodzić się należy ze Stefanem Zameckim, że jego propozycje w tym zakresie nie stały się źródłem inspiracji dla polskich historyków nauki:

Znaniecki jako teoretyk naukoznawstwa nie został badawczo skonsumowany w gronie historyków dziedziny „nauka”. Trudno zrozumieć dlaczego polscy historycy nauki dziedziny „nauka” [...] zignorowali fakt napisania przez Znanieckiego omawianej wyżej rozprawy [Przedmiot i zadania nauki o wiedzy, 1925 r. - przyp. J.J.], nawet nie podejmując polemiki z jego poglądami, nie mówiąc już o wyrażeniu swej aprobaty. Pisarstwo jego nie należy wszak do tuzinkowych ${ }^{10}$. 
Decydował o tym być może fakt, że polscy historycy nauki hołdowali często kumulacyjnej wizji rozwoju nauki, pozostając $w$ dobie PRL-u przynajmniej formalnie pod wpływem marksizmu. Podejmowane od lat sześćdziesiątych minionego stulecia próby konstruowania społecznej wizji dziejów nauki opierały się częściej na pracach T.S. Kuhna czy też L. Flecka (w tej kolejności, wbrew chronologii powstawania ich dzieł), nie zaś Znanieckiego, choć próby popularyzowania jego dorobku były już widoczne w latach osiemdziesiątych ubiegłego stulecia, jednak głównie w środowiskach historyków socjologii, nie zaś jako model badań historyczno-naukowych $\mathrm{np}$. w konstruowaniu prac syntetycznych. Stefan Zamecki zauważył w tym kontekście, że

interesujące jest zwrócenie uwagi Znanieckiego na występowanie rewolucji naukowych w sferze poglądów. Suponować można, że niektóre poglądy, rozproszone w jego rozprawie mogły inspirować późniejszych autorów [...] Ludwika Flecka, a za jego pośrednictwem Thomasa Samuela Kuhna ${ }^{11}$.

Postawiona przez prof. Zameckiego teza jest rzeczywiście godna rozważań, jej zasadność mogłaby bowiem ukazać drogi krążenia idei pomiędzy środowiskami nauk medycznych i społecznych zainteresowanych przeszłością konstruowania wiedzy.

Zagadnienie to było jednak obszarem refleksji Jerzego Kmity. Poznański metodolog ukazał związki pomiędzy koncepcją Znanieckiego a teorią paradygmatów, choć nie rozstrzygnął kwestii mechanizmu recepcji myśli Znanieckiego, o którą pytał Zamecki, pominął także postać pośredniczącego w ewentualnym procesie recepcji Ludwika Flecka, koncentrując się na zbieżności idei Znanieckiego i Kuhna. Uważał bowiem, że

rezultaty praktyki badawczej danego okresu historycznego, w szczególności teorie naukowe wyposażone są w określony społeczny współczynnik humanistyczny. [...] W gruncie rzeczy zatem głównym osiągnięciem T.S. Kuhna jest wprowadzenie własnego terminu „paradygmat” dla metodologiczno-teoretycznego współczynnika humanistycznego kolejnych stadiów rozwoju wiedzy naukowej oraz podkreślenia jego roli jako społeczno-subiektywnej bazy wykrystalizowania się standardu „naukowości"12.

Zarówno Znaniecki, jak i Kmita w swoich koncepcjach nauki dużą wagę przywiązywali do genezy w procesach kształtowania się systemów wiedzy, choć postrzegali je odmiennie. Dla Znanieckiego istotny był związek genetyczno-logiczny, czy też "genetyczno-opisowa systematyka zjawisk poznawczych", a dla Kmity funkcjonalno-genetyczny. Trudno jednak stwierdzić, czy ten drugi inspirował się myślą pierwszego w tej materii. W praktyce historiograficznej polscy historycy nauki nie sięgali po inspiracje tkwiące w koncepcjach Floriana Znanieckiego, choć walor płodności intelektualnej w tym zakresie zachowały one do dziś. Szczególnie tam, gdzie odnoszą się do zmiennych zakresów wiedzy naukowej w przeszłości oraz cyrkulacji idei naukowych i ich adaptacji w różnych środowiskach kulturowych. Problematyka ta jest obecnie wśród europejskich i amerykańskich historyków nauki bardzo aktualna. Stefan Zamecki zasygnalizował zatem ważne zjawisko, choć ze

11 Ibid., s. 56.

12 J. Kmita, Szkice z teorii poznania naukowego, Warszawa 1976, s. 113-114, 121. 
względu na chronologię odniósł się tylko do procesów zachodzących w okresie międzywojennym.

Zostawił on wszakże w swoich rozważaniach nad pierwszym polskim naukoznawczym periodykiem otwarte pole badawcze: analizę zawartych na łamach „Nauki Polskiej” treści ponad dwustu recenzji książek z Wielkiej Brytanii, Niemiec, USA, Francji, Polski, a także Austrii, Związku Radzieckiego czy Szwajcarii. Zapewne byłby to materiał na odrębną książkę, ukazującą źródła inspiracji i krążenie idei naukowych wśród ówczesnych luminarzy polskiej nauki. Autor zauważa także, że niektóre prace oraz ich recenzje „miały swoje przedłużenie w publikacjach ogłaszanych po II wojnie światowej w Polsce”. Ma tu na myśli przede wszystkim prace Kuhna i Flecka. Wymienia także najaktywniejszych recenzentów, a wśród nich Marię Ossowską, Czesława Białobrzeskiego, Stanisława Ossowskiego, Jana Drewnowskiego, Bogdana Suchodolskiego, Stefana Błachowskiego, Jerzego Siwickiego, Pawła Rybickiego czy Stanisława Herbsta. Nazwiska autorów recenzji wiele mówią o randze pisma, na łamach którego je publikowali. Mamy tu do czynienia z wybitnymi uczonymi, twórcami oryginalnych koncepcji naukowych, także w obrębie rodzącego się polskiego naukoznawstwa. Z perspektywy historyka nauki nie jest bez znaczenia, jaka była ich pozycja w zachodzących wówczas procesach inspiracji - recepcji idei w reprezentowanych przez nich dyscyplinach naukowych. Stefan Zamecki zwraca na ten problem uwagę, a „Nauka Polska” dostarcza materiału. Przyszła książka poszukuje autora...

W drugiej poświęconej „Nauce Polskiej” książcem O niektórych potrzebach nauki polskiej na łamach periodyku "Nauka Polska Jej Potrzeby, Organizacja i Rozwój”. Lata 19181947. Aneks (Warszawa 2017), autor przyjął odmienną od poprzedniej perspektywę interpretacji dorobku tytułowego periodyku z międzywojennego okresu pisma. Owe tytułowe dla książki i pisma „potrzeby” są tutaj rozumiane znacznie dosłowniej, niż w poprzedniej książce Zameckiego, gdzie interpretował je głównie jako wizje tworzącej się samodzielnej nauki polskiej porozbiorowej doby. Większość ma powtarzający się charakter: nowe katedry, młoda kadra, finansowanie, czasopisma naukowe itp. Nietrudno zrozumieć te potrzeby w dobie odradzającego się państwa polskiego i w kontekście innych, niekiedy zdaniem decydentów znacznie ważniejszych potrzeb.

Te omawiane na łamach „Nauki Polskiej” potrzeby, analizowane przez autora, najczęściej organizacyjne, dotyczące różnych grup nauk stanowiły nie tylko ogólną diagnozę zjawiska, przydatną w ówczesnej polityce naukowej państwa, lecz także sugestie dla kierunków aktywności Kasy im. Józefa Mianowskiego, która dla „Nauki Polskiej” była i jest wydawcą. Zresztą książka Zameckiego zwraca uwagę na niektóre aspekty działalności tej zasłużonej organizacji. Autor zauważył wszakże, że niektóre elementy owych diagnoz sprzed blisko stu lat brzmią niepokojąco współcześnie, choć zmianie w tym czasie uległy niemal wszystkie możliwe typy uwarunkowań wpływających na świat nauki. W tym kontekście pojawiał się też problem finansowania publikacji młodej kadry, a Stefan Zamecki zauważa także współczesną jego aktualność. Ta jest widoczna również w przywołanej przez niego wypowiedzi Tadeusza Kotarbińskiego z 1918 r., wskazującej, że „za dowód intensywności i głębokości takiej pracy nie może uchodzić żadną miarą liczba arkuszy oryginalnych publikacji"13. Niektóre propozycje miewały jednak systemowy i oryginalny

13 S. Zamecki, O niektórych potrzebach nauki polskiej na łamach periodyku "Nauka Polska Jej Potrzeby, Organizacja i Rozwój. Lata 1918-1947. Aneks, Warszawa 2017, s. 311. 
charakter, np. „planowego uprzywilejowania jednego działu nauk na każdym z polskich uniwersytetów"14, czy też powołania nieakademickich instytutów badawczych ${ }^{15}$. Autor książki wskazuje w tym miejscu na obecność tego rodzaju postulatów także w obecnych dyskusjach nad nauką. W ciekawy sposób do problemu praktycznej użyteczności filozofii odniósł się w 1924 r. cytowany przez autora Władysław Witwicki, pisząc:

Zaślepienie, jednostronność, bezkrytyczna wiara, to są czynniki pożądane dla przywódców każdego masowego ruchu. [...] One zawsze sprzyjają masowym sugestiom, ułatwiają fanatyzowanie mas. Nie popierają zaś nauk filozoficznych; nauka zwykła zmniejszać sugestywność, ujmować powagi autorytetom. [...] Zapominają tylko o tym, że brak krytycyzmu zwiększa podatność nie tylko dla państwa pożądane, ale równie dobrze sugestie inne, dla państwa niebezpieczne i groźne. Jeżeli przez Polskę rozumieć jedynie organizację państwową i brać pod uwagę tylko materialne straty i pożytki, łatwo można nie dojrzeć strat, które by ta organizacja ponosić miała na nie dostatecznym uprawianiu filozofii ${ }^{16}$.

I w innym miejscu dodawał: „walki stronnictw kosztują nieobliczalne sumy. Kosztowałby mniej, gdyby do walk stawiano na miejscach naczelnych ludzi z pewną kulturą filozoficzną"17. Stefan Zamecki zwraca uwagę na pojawiające się na łamach „Nauki Polskiej” postulaty dotyczące popularyzacji nauki. Cytuje jednak także w tym kontekście Kazimierza Tymienieckiego, który przestrzega, pisząc aktualne także dzisiaj słowa, że „wysoce zasłużeni uczeni porwani prądem ogólnym stają się publicystami. [...] Publicystyka nie zastąpi nauki i odwrotnie. Gdy jednak pierwsza z natury rzeczy odznacza się zmiennością i zależy od chwili, to druga na innych zasadach budować powinna"18.

Zaprezentowane przez Zameckiego poglądy na potrzeby organizacji nauki zawierają także problemy postaw etycznych uczonych, szczególnie aktualne w dobie przełomów społecznych i politycznych. Przywołany przez niego Stanisław Małkowski pisał w 1947 r. na podstawie swoich wieloletnich przemyśleń:

W osobach swych pracowników: całych rzesz jednostek oraz zespołów nauka była ujarzmiana przez kapitał, przez doktryny polityczne, społeczne i wyznaniowe, przez państwo. Wartości naukowe, posiadłszy swą wysoką cenę, stawały się przedmiotem zabiegów o ich pozyskanie, przedmiotem handlu, kradzieży i rabunku oraz gwałtu i prostytucji. [...] Służba nauce wymaga zatem posiadania siły moralnej, która umożliwia pracownikowi spełnienie jego obowiązku, jakim jest wskazywanie prawdy naukowej lub dążenie do niej bez względu na osobiste tego następstwa. Twarde to naczelne wymaganie sprawia, że służbę nauce otacza pewien urok, odmienny od uroku służby wojskowej na froncie, lecz nieco jej pokrewny"19. 
Autor książki podkreśla, że „od jego pierwszego publikowania minęło już 70 lat, prezentuje poglądy, które [...] nie straciły zbyt wiele na aktualności"20. Autor Życia wśród innych wśród "stuletnich aktualiów" widocznie zauważył obecność nie tylko wiecznotrwałych problemów natury organizacyjnej, finansowej i kadrowej.

"Trylogię" zamyka książka Problematyka naukoznawcza na łamach periodyku "Nauka Polska Jej Potrzeby, Organizacja i Rozwój". Studium historyczno-metodologiczne. Lata 1992-2016 (Warszawa 2018). Autor przyjął zasadę szczegółowej analizy poszczególnych tomów. Naukoznawcze zainteresowania prof. Zameckiego kazały mu jednak wyodrębnić i podkreślić reaktywowanie w 1992 r. wraz z „Nauką Polską" Konwersatorium Naukoznawczego, wpływowego forum wymiany myśli z okresu międzywojennego. Sprawozdania z tych spotkań stanowiły w dobie międzywojennej istotny składnik kolejnych tomów „Nauki" i redakcja jej odnowionej edycji pod kierownictwem Jana Piskurewicza kontynuowała ten zwyczaj. Odbyło się dziesięć udokumentowanych, szczegółowo analizowanych przez Zameckiego spotkań, a na liście dyskutantów znaleźć można luminarzy nauki polskiej lat dziewięćdziesiątych ubiegłego stulecia, a także kilka postaci bardziej znanych kilka lat później. Zakończenie działalności Konwersatorium w 1998 r. wywołało u autora książki uczucia pustki i żalu. Nie interpretuje jednak szerzej tego faktu, zwracając jedynie uwagę na kwestie finansowe ${ }^{21}$. Jednakże idea reaktywacji takiego naukoznawczego forum przy Kasie im. Józefa Mianowskiego jest Stefanowi Zameckiemu nadal bliska. Gdy objąłem redakcję „Rocznika Kasy”, zostałem przez niego zapytany o możliwość reaktywowania Konwersatorium. Kwestię tę uważam za otwartą i złożoną, z pewnością też niepozostającą wyłącznie, a nawet nie przede wszystkim, w gestii skromnego redaktora czasopisma naukowego. Oceniając kompleksowo warunki obecności na rynku wydawniczym „Nauki Polskiej", Zamecki podkreśla, że pismo działa w warunkach silnej konkurencji innych periodyków o charakterze naukoznawczym: „Z tego względu, niektóre ważkie teksty, które ze względów merytorycznych z powodzeniem mogłyby zostać opublikowane na łamach "Nauki Polskiej», są drukowane w takim czy innym periodyku o profilu również naukoznawczym" 22. Podzielając tę diagnozę mogę jedynie dodać, że nadzieją dla czasopisma Kasy Mianowskiego może być bardziej refleksyjny niż ściśle naukoznawczy charakter, gdy uda się pozyskać wybitnych autorów prezentujących swoje osobiste stanowiska wobec różnych segmentów nauki polskiej. Znakiem wyróżniającym „Naukę Polską" mogłyby stać się z czasem autobiografie czołowych polskich uczonych, co również należy uznać za formę refleksji i było niegdyś z powodzeniem praktykowane przez redakcję „Kwartalnika Historii Nauki i Techniki". W tych mniej sformalizowanych wypowiedziach możliwe jest bowiem przedstawienie nurtów życia naukowego i czynników je kształtujących, niedostępnych w oficjalnych dokumentach o instytucjonalnym charakterze, natomiast niezwykle ważnych dla historyka nauki.

Twórczość Stefana Zameckiego charakteryzuje się pewną specyficzną cechą: znaczną część jego tekstów stanowią przywoływane przez niego, niekiedy bardzo obszerne, cytaty. Spotyka się to czasem z krytyką. Ma jednak sporą zaletę, można je bowiem niekiedy

21 S. Zamecki, Problematyka naukoznawcza na łamach periodyku "Nauka Polska Jej Potrzeby, Organizacja i Rozwój". Studium historyczno-metodologiczne. Lata 1992-2016, Warszawa 2018, s. 305-306.

22 Ibid., s. 444. 
potraktować jako krytyczny, poddany szczegółowej analizie, wybór źródeł. Ostatecznie oddawanie głosu źródłom dla uwiarygodnienia własnych poglądów ma bardzo długą tradycję i Stefan Zamecki po prostu się w nią wpisuje. Dla zajętego badacza ta maniera uczonego bywa dużym ułatwieniem w jego studiach. Zresztą autor ten nigdy nie ukrywał, że „lubi sobie zacytować".

Stefan Zamecki, uczony krytyczny, sceptyczny i zdystansowany, szedł do historii nauki (historia dziedziny nauka w jego nomenklaturze) poprzez studia chemiczne i filozoficzne. To ukształtowało jego teoretyczne, "graniczne” postawy, lokując je jednak nieco poza głównym nurtem studiów w tej dziedzinie. Używając terminologii Ludwika Flecka, ideowo znalazł się trochę poza głównymi kolektywami i stylami myślowymi obecnymi w obszarze polskiej historiografii nauki, choć instytucjonalnie związany jest od kilku dekad właśnie z Instytutem Historii Nauki PAN. Profesor wybrał więc rolę trudną, ale dla niektórych bardzo inspirującą. Zaliczam się do tych ostatnich.

\section{Bibliografia}

Jeszke J., Wokół statusu historii nauki w Polsce jako dyscypliny naukowej, „Nauka Polska.

Jej Potrzeby, Organizacja i Rozwój" t. 25 (50) 2016, XXV, s. 65-84.

Kmita J., Szkice z teorii poznania naukowego, Warszawa 1976.

Zamecki S., O niektórych potrzebach nauki polskiej na łamach periodyku "Nauka Polska Jej Potrzeby, Organizacja i Rozwój. Lata 1918-1947. Aneks, Warszawa 2017.

Zamecki S., Pojęcie odkrycia naukowego a historia dziedziny nauki, Wrocław, Warszawa, Kraków, Gdańsk, Łódź 1988.

Zamecki S., Problematyka naukoznawcza na łamach periodyku „Nauka Polska Jej Potrzeby, Organizacja i Rozwój". Studium Historyczno-metodologiczne, lata 1918-1947, Warszawa 2016.

Zamecki S., Problematyka naukoznawcza na łamach periodyku "Nauka Polska Jej Potrzeby, Organizacja i Rozwój". Studium historyczno-metodologiczne. Lata 1992-2016, Warszawa 2018.

Zamecki S., Życie wśród innych, Warszawa 2019.

dr hab. Jaromir Piotr Jeszke, prof. UAM, historyk nauki i antropolog wiedzy. Profesor w Uniwersytecie im. Adama Mickiewicza w Poznaniu. Kieruje Zespołem ds. Historycznych i Społecznych Problemów Nauki Centrum Uniwersyteckiego „Pracownia Pytań Granicznych" UAM. Redaktor Naczelny Rocznika Kasy im. J. Mianowskiego „Nauka Polska. Jej Potrzeby, Organizacja i Rozwój”. W swoich badaniach podejmuje problematykę historii i antropologii wiedzy medycznej, historii historiografii i metodologii badań nad nauką. Zajmuje się także problematyką roli historii w procesie komunikacji międzykulturowej.

e-mail: jeszke@amu.edu.pl

Data zgłoszenia artykułu: 25 listopada 2019

Data przyjęcia do druku: 2 grudnia 2019 